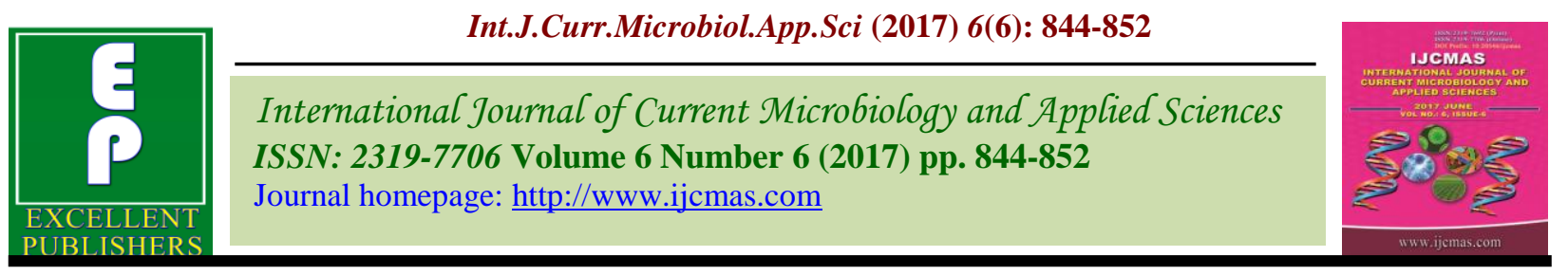

Original Research Article https://doi.org/10.20546/ijcmas.2017.606.099

\title{
Prevalence of Seed mycoflora of Mung bean (Vigna radiata L.) in Karnataka, India
}

\author{
B.D. Devamani", M. Saifulla, Jayappa and Jabbar Sab \\ Department of Plant Pathology, College of Agriculture, UAS, GKVK, Bengaluru 560065, India \\ *Corresponding author
}

\author{
A B S T R A C T
}

\begin{tabular}{l} 
Ke y w o r d s \\
Mung bean, \\
Seed, \\
Mycoflora, \\
Infection, \\
Districts etc. \\
\hline Article Info \\
\hline $\begin{array}{l}\text { Accepted: } \\
14 \text { May } 2017 \\
\text { Available Online: } \\
\text { 10 June } 2017\end{array}$ \\
\hline
\end{tabular}

\section{Introduction}

Mung bean [Vigna radiata L. Wilczek, syn. Phaseolus aureus Roxb, $P$. radiates L.] is the third most important pulse crop among the thirteen food legumes grown in India. It is also commonly known as green gram, which is an ancient and well known leguminous crop of Asia. In India, the name green gram is more commonly used than mung bean (Chatterjee and Randhawa, 1952). This crop is native to Indo-Burma region of South-East Asia. It is cultivated extensively in the IndoBurma-Thailand region of Asia.

Mung bean contains about 24 per cent protein, which is about two third of the protein content of soybean, twice that of wheat and thrice that of rice.
The protein present in mung bean is comparatively rich in lysine, an amino acid that is deficient in cereal grains which are rich in methionine, cystine and cysteine, the sulphur bearing amino acids. Therefore, a diet combining mung bean and cereal grains form a balanced amino acid diet.

Mung bean is grown mainly as a Kharif crop. However, its cultivation in Rabi is restricted to the eastern and southern parts of the country. The major mung bean growing states are Odisha, Maharashtra, Andhra Pradesh, Rajasthan, Karnataka and Gujarat. It ranks third among all pulses grown in India after chickpea and pigeon pea. In India, the total 
production of mung bean is 15 lakh tonnes from an area of 34.40 lakh ha with a productivity of $406.98 \mathrm{~kg} \mathrm{ha}^{-1}$, of which Karnataka occupies 5.28 lakh ha with a production of 1.08 lakh tonnes and average yield of $204.55 \mathrm{~kg} \mathrm{ha}^{-1}$ (Anonymous, 2011).

Among the various factors responsible for low yields, biotic and abiotic stresses take a heavy toll of the crop, out of which diseases cause an estimated yield loss of 20 to 30 per cent (Singh, 1995). Green gram suffers from many diseases caused by fungi, bacteria, viruses, nematodes and also abiotic stresses. Among the fungal diseases, powdery mildew, anthracnose, Cercospora leaf spot, web blight and dry root rot are the most prevalent diseases. Apart from foliar and soil borne diseases, same fungi are also causing qualitative and quantitative loss in the storage.

Seed is the focal point in agriculture development without which an agriculture system is meaningless (Schwin, 1994) and high quality seed is an important pre-requisite for sustainable and profitable crop production. Seed health is an important factor in the control of diseases, since an infected seed is less viable, has low germination, reduced vigour and reduced yield (Van Gastel et al., 1996).

Diseases and injuries to seeds are caused by micro-organisms including virus, bacteria, fungi and nematodes. Among the parasitic organisms, the fungi are frequently encountered on seeds (Neergaard, 1977). The control of seed borne pathogens is the first step in any agricultural crop production and protection programme.

Storage fungi do not invade before the harvest, but they may be found on the seeds in low percentages often below one per cent. Seeds are known to carry a considerable amount of microorganisms. Some of these cause various diseases. Pathogens are associated with seeds in the form of contaminants, externally and internally as seed borne. These organisms become active under favourable condition and affect seed germination which results in lower plant population and abnormal seedlings in field, thereby causing considerable reduction in yield (Christensen and Lopez, 1963).

Invasion by fungi in storage might result in the discoloration of the seeds, rise in temperature, mustiness, loss in weight and various changes in the seed constituents. Some of the seeds infecting fungi produce mycotoxins such as aflatoxin, patulin, citrinine and ochratoxin (Bilgrami et al., 1979).

The seed mycoflora are carried over from year to year and from one place to another with the seeds which serve as primary source of infection for subsequent crops. Management of seed borne diseases has been reasonably achieved through fungicides and biological agents. Seed treatment is one of the important methods in the integrated management of any disease and has provided excellent results in reducing losses caused by diseases with increase in quality and quantity of seed, although chemicals have been successful in managing the diseases but they are hazardous to the environment apart from the possibility of the toxicity getting into the growing plant and finally into the food chain. Therefore, seed must be "substantially free" from inoculum with high level of germination and purity before sowing.

Presently, the information on the mung bean seed mycoflora is meagre. Hence, there is a need to generate information on the prevalence of seed mycoflora. Keeping this in view, present investigation was envisaged.

\section{Materials and Methods}

The present investigations on seed mycoflora 
of mung bean (Vigna radiata L.) included identification of seed mycoflora on mung bean samples collected from different districts of Karnataka. The investigations were carried out at the College of Agriculture, University of Agricultural Sciences, GKVK, Bengaluru during 2014-2016.

Collection of mung bean seeds for the identification of seed mycoflora in different districts of Karnataka

To identify seed mycoflora prevailing in different districts, eighteen seed samples were collected from thirteen different districts viz., Bagalkot, Bengaluru, Chamrajanagar, Chikkballapur, Chitradurga, Davanagere, Dharwad, Hassan, Kalaburgi, Mandya, Mysuru, Raichur and Tumakuru of Karnataka. While two samples were collected from Davanagere (Harihar and Davanageretaluk), Chikkabalapura (Gauribidanur and Chikkabalapurataluk), Mysuru (Hunsur and Mysurutaluk), Raichur (Lingsugur and Raichurtaluk), Tumakuru (Tiptur and Tumakurutaluk) districts; only one sample was collected from Bagalkot, Bengaluru, Chamrajanagar, Chitradurga, Dharwad, Hassan, Kalaburgi, Mandya districts.

\section{Seed mycoflora}

Eighteen seed samples of mung bean were collected from different districts of Karnataka and assayed for seed mycoflora by employing standard blotter method as per the International Rules for Seed Testing. According to ISTA (Anonymous, 1996), four hundred seeds of each sample were placed equidistantly, aseptically on three layers of moist blotters moistened with sterile distilled water in sterile Petriplates of $90 \mathrm{~mm}$ diameter at the rate of twenty-five seeds per plate and the plates were incubated for seven days under diurnal cycles of $12 \mathrm{~h}$ light and $12 \mathrm{~h}$ darkness at room temperature of $28 \pm 1{ }^{\circ} \mathrm{C}$.
After incubation seed mycoflora was recorded on eighth day by observing fungal growth on seeds under stereo binocular microscope. Further, the species were confirmed by preparing slides and their frequency of occurrence was expressed in percentage.

\section{Identification of seed mycoflora}

The seed mycoflora were identified by studying the morphological characters of the fungus and referring to the "The genera of fungi sporulating in pure culture (Von Arx and Cramer, 1981), Hyphomycetes taxonomy and biology (Subramanian, 1983), the genus Fusarium (Booth, 1971) and Illustrated genera of imperfect fungi (Burnett, 1972).

\section{Results and Discussion}

Seeds samples collected from different districts were plated on moist blotters by following the standard blotter method. The observations were recorded and the data is presented in table 1, figure 1 and plate 1. Twelve fungi belonging to ten genera viz., Aspergillus niger, Alternaria alternata, Aspergillus flavus, Aspergillus candidus, Penicillium notatum, Rhizopus stolonifer, Cladosporium sp., Fusarium oxysporum, Mucor sp., Curvularia lunata, Macrophomina phaseolina and Chaetomium globosum were observed in all the eighteen mung bean seed samples collected from different districts.

Prevalence of seed mycoflora in seed samples revealed that seed sample collected from Bagalkottaluk of Bagalkot district, recorded maximum association of $P$. notatum (46\%) followed by $F$. oxysporum (38 \%), $M$. phaseolina (30 \%), A. niger (22 \%), Cladosporium sp. (18\%), A. flavus (14\%), A. candidus (9\%), A. alternata (7\%), C. lunata (4\%), R. stolonifer (4\%), Mucor sp. (2 \%) and $C$. globosum (2\%).Obtained results were in conformity with Tripti Agarwal et al., 
(2011), they isolated A. alternata, Chaetomium spp., Penicillium citrinum, Aspergillus niger, A. flavus, Rhizopus nigricans, Fusarium oxysporum from the collected samples of chickpea, lentil and black gram seeds. Mukhtar et al., (2007) also reported association of similar mycoflora in lentil seeds.

Seed sample collected from Bengaluru north taluk of Bengaluru district showed prevalence of seed mycoflora with maximum association of $F$. oxysporum (59 \%) followed by $P$. notatum $(34 \%), \quad$ A. flavus $(21 \%)$, Cladosporium sp. (16\%), A. niger (14\%), M. phaseolina (12\%), A. alternate (4 \%), R. stolonifer (4\%), Mucor sp. (3\%), C. lunata (2\%) and A. candidus (2\%). Rauf (2000) also recorded Alternaria alternata, Ascochyta spp., Colletotrichum spp., Fusarium spp. and Macrophomina phaseolina as the most frequent fungi in legume crop seeds.

Seed sample collected from the Chamarajanagar taluk of Chamarajanagara district recorded maximum association of $F$. oxysporum $(50 \%)$ followed by $P$. notatum (46\%), Cladosporium sp. (24\%), A. niger (18\%), A. flavus (16 \%), M. phaseolina (14\%), R. stolonifer (4\%), C. lunata (3\%), C. globosum (3\%), A. aternata (2\%) and Mucor sp $(1 \%)$.

Similar mycoflora association was also reported by Chakravarthy et al., (2001), Tomar et al., (2002), Raij Naik and Papanna (2001) and Ramesh and Avitha Marihal, 2002).

Out of two seed samples collected from Chikkaballapura district, sample from Gauribidanurtaluk recorded maximum association of seed mycoflora. Maximum association was by $F$. oxysporum (40 \%) followed by $P$. notatum (38 \%), A. niger (17 $\%)$, M. phaseolina (14\%), Cladosporium sp.
(8\%), A. flavus (8\%), C. globosum (3\%), A. candidus (2\%), A. aternata $(2 \%)$ and $C$. lunata (1 \%). Seed sample collected from Chikkaballapurataluk of showed the maximum association of $P$. notatum (30\%), followed by $F$. oxysporum (24 \%), $M$. phaseolina (20\%), Cladosporium sp. (14\%), A. flavus (12\%), A. niger (10\%), Mucor sp. (5\%), A. candidus (4\%), R. stolonifer (2\%) and $C$. globosum (1\%). The findings of Shalini Vermaand Dahroo (2003) were also the same type of mycoflora association with pea seeds. They recorded Fusarium oxysporum, Alternaria alternata, Aspergillus flavus, A. niger, Pythium aphanidenriatum, Pythium ultirmim, Gliocladium virens, Cladosporium herbarum, Rhizopus nigricans, Mucor sp, Dactylaria sp, Geotrichum and Rhizopus stolonifer

Seed sample collected from Hiriyurtaluk of Chitradurga district recorded maximum association of $F$. oxysporum (39\%) followed by $P$. notatum (32\%), A. niger (27\%), A. flavus (20 \%), M. phaseolina (12\%), Cladosporium sp. (12 \%), R. stolonifer (10 $\%)$, A. alternata (8\%), C. lunata (4\%), A. candidus (4\%) and C. globosum (2\%). Similar kind seed mycoflora association was noted by Dawar et al., (2007) and Venugopal Rao et al., (2015).

Out of two seed samples collected from Davanagere district, sample from Harihartaluk recorded maximum association of seed mycoflora. Maximum association was by $P$. notatum $(54 \%)$ followed by $F$. oxysporum. (36\%), A. flavus (22\%), A. niger (19\%), A. candidus (10\%), M. phaseolina (10\%), Cladosporium sp. (6 \%), C. lunata (4\%), R. stolonifer (2\%) and Mucor sp. (1\%). Seed sample collected from Davanageretaluk showed the maximum association of $F$. oxysporum (46\%), followed by $P$. notatum (39\%), A. niger (21\%), Cladosporium sp. (14 \%), A. flavus (13 \%), M. phaseolina 
(10\%), R. stolonifer (8\%), A. candidus (4\%), A. alternata (2\%), Mucor sp. (2\%) and C. globosum (1 \%). Narayan and Ayodhya (2013) reported similar Fusarium oxysporum, F. moniliform, F. solani, Chaetomium sp, Curvularia lunata, Macrophomina sp., Alternaria alternata, Chaetomium spp., Penicillium citrinum, Aspergillus niger, A. fumigatus, A. flavus, Rhizopus nigricans, Moniliasp., Penicillium sp., Rhizoctonia sp., and Trichoderma sp. mycoflora with pea, horse gram and green gram seeds. Seed sample collected from Dharwad taluk of
Dharwad district recorded maximum association of $F$. oxysporum (44\%) followed by $P$. notatum (28\%), A. niger (23\%), A. flavus (18\%), Cladosporium sp. (15\%), A. candidus (12\%), M. phaseolina (6\%), $R$. stolonifer (6\%), C. lunata (6\%), A. aternata (5\%), C. globosum (4\%) and Mucor sp. (2\%). Ramesh et al., also reported $M$. phaseolina (27.0 - 28.0\%), F. oxysporum (5.0 - 5.5\%), A. flavus (7.0\%) and A. niger (3.54.0\%) from the seed storage units and APMC market, Raichur in 2013.

Plate.1 Mycoflora on seeds after incubation on standard blotter
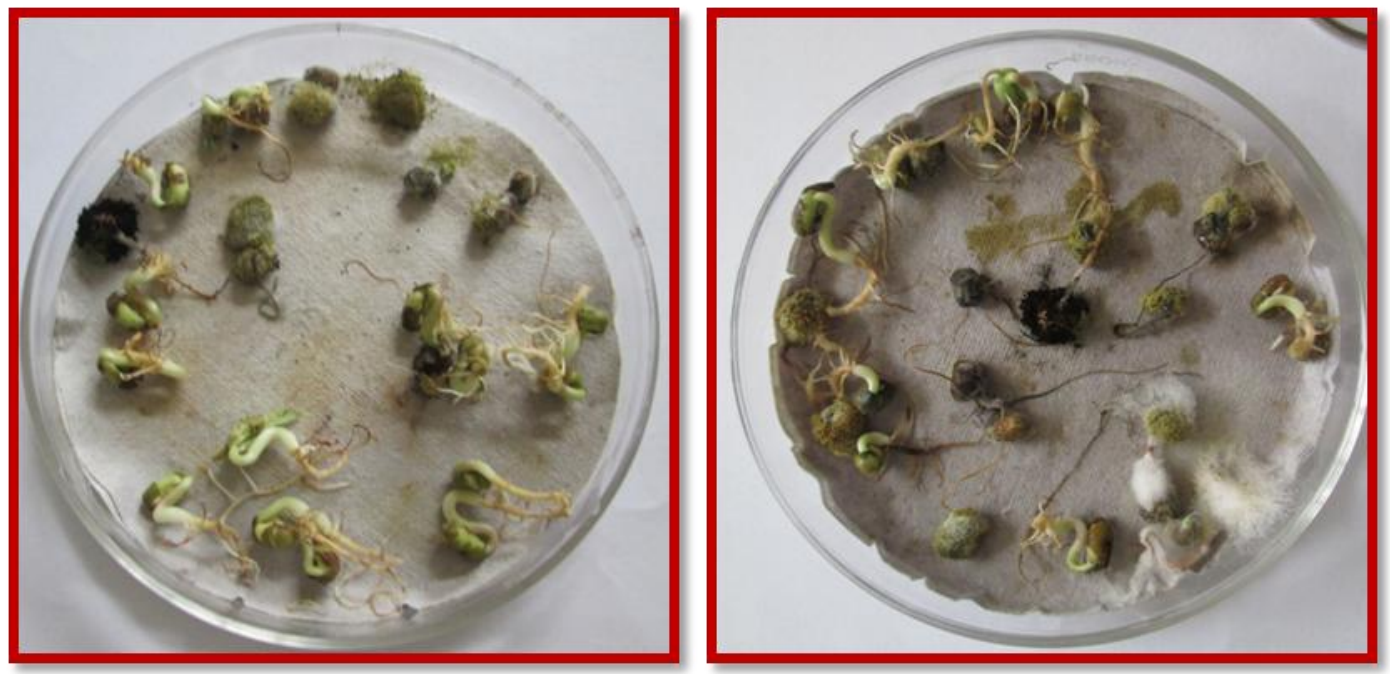

Fig.1 Mung bean seed mycoflora in Karnataka

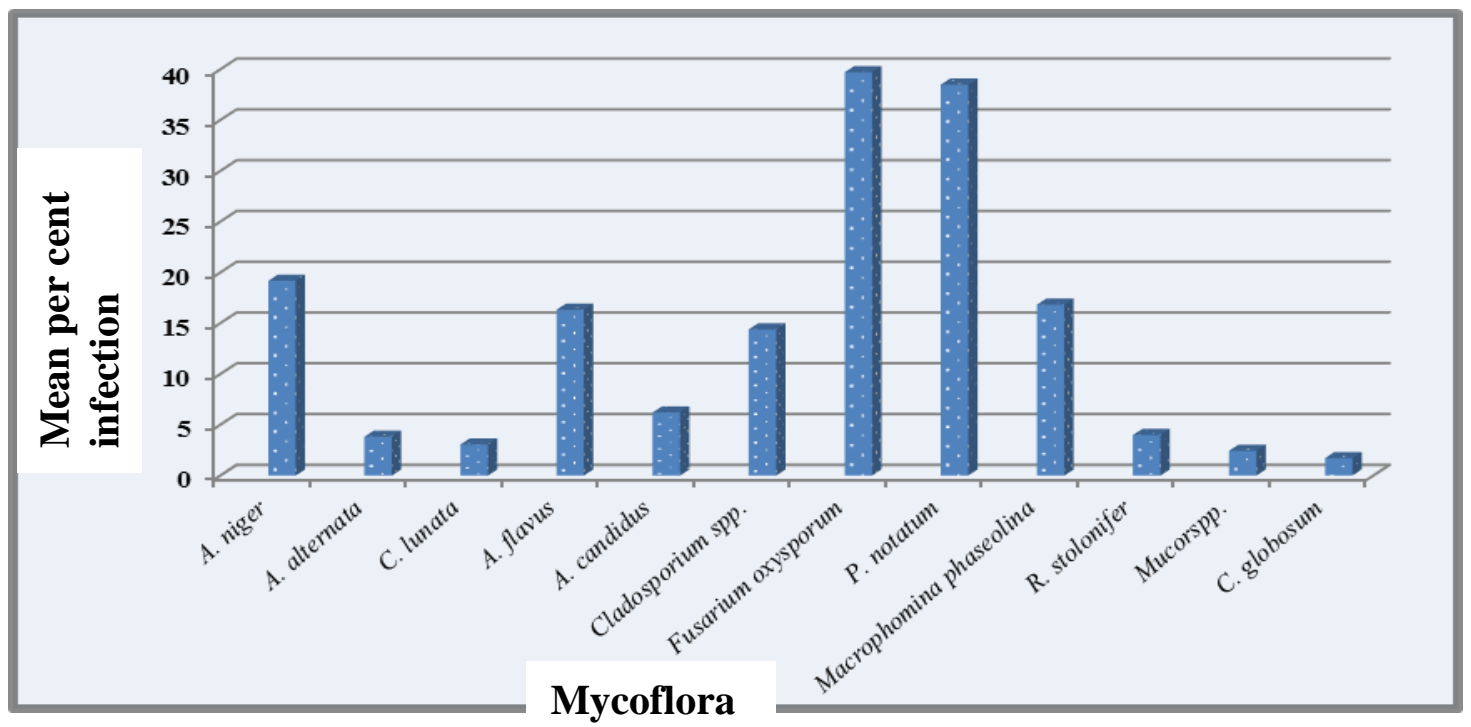


Table.1 Association of seed mycoflora in seeds of mung bean collected from different districts of Karnataka

\begin{tabular}{|c|c|c|c|c|c|c|c|c|c|c|c|c|c|c|c|c|}
\hline \multirow[b]{2}{*}{$\begin{array}{l}\text { Sl. } \\
\text { No }\end{array}$} & \multirow[b]{2}{*}{ Districts } & \multirow[b]{2}{*}{ Taluks } & \multirow[b]{2}{*}{ 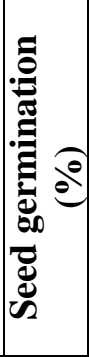 } & \multicolumn{13}{|c|}{ Per cent seed mycoflora } \\
\hline & & & & 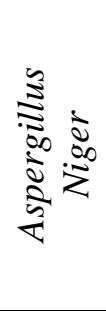 & 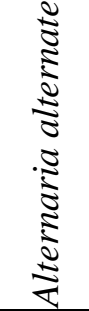 & 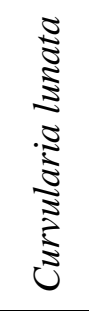 & 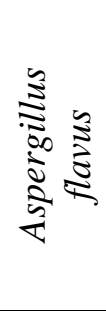 & 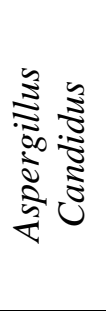 & 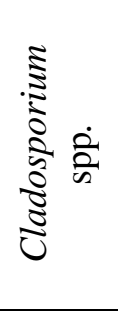 & 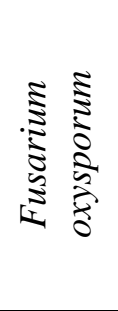 & 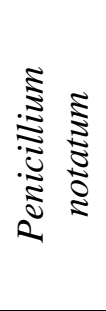 & 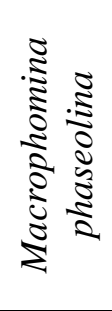 & 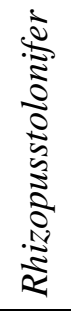 & 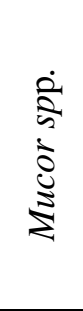 & 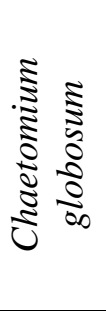 & 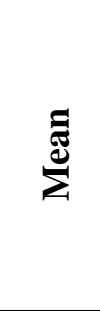 \\
\hline 1. & Bagalkot & Bagalkot & 81 & 22 & 7 & 4 & 14 & 9 & 18 & 38 & 46 & 30 & 4 & 2 & 2 & 16.33 \\
\hline 2. & Bengaluru & $\begin{array}{l}\text { Bengaluru } \\
\text { North }\end{array}$ & 91 & 14 & 4 & 2 & 21 & 2 & 16 & 59 & 34 & 12 & 4 & 3 & 0 & 14.25 \\
\hline 3. & Chamarajnagar & Chamarajnagar & 85 & 18 & 2 & 3 & 16 & 0 & 24 & 50 & 46 & 14 & 4 & 1 & 3 & 15.08 \\
\hline \multirow{2}{*}{4} & \multirow{2}{*}{ Chikkaballapura } & Chikkaballapura & 86 & 10 & 0 & 0 & 12 & 4 & 14 & 24 & 30 & 20 & 2 & 5 & 1 & 10.17 \\
\hline & & Gauribidanur & 95 & 17 & 2 & 1 & 8 & 2 & 8 & 40 & 38 & 14 & 0 & 0 & 3 & 11.08 \\
\hline 5. & Chitradurga & Hiriyur & 75 & 27 & 8 & 4 & 20 & 4 & 12 & 39 & 32 & 12 & 10 & 0 & 2 & 14.17 \\
\hline \multirow{2}{*}{6} & \multirow{2}{*}{ Davanagere } & Harihar & 88 & 19 & 0 & 4 & 22 & 10 & 6 & 36 & 54 & 10 & 2 & 1 & 0 & 13.67 \\
\hline & & Davanagere & 93 & 21 & 2 & 0 & 13 & 4 & 14 & 46 & 39 & 10 & 8 & 2 & 1 & 13.33 \\
\hline 7. & Dharwad & Dharwad & 87 & 23 & 5 & 6 & 18 & 12 & 15 & 44 & 28 & 6 & 6 & 2 & 4 & 14.08 \\
\hline 8. & Hassan & Hassan & 90 & 16 & 4 & 2 & 15 & 0 & 25 & 28 & 41 & 20 & 0 & 6 & 0 & 13.08 \\
\hline 9. & Kalaburgi & Kalaburgi & 78 & 36 & 10 & 8 & 30 & 14 & 26 & 65 & 62 & 46 & 12 & 8 & 2 & 25.73 \\
\hline 10. & Mandya & Srirangapattana & 87 & 18 & 0 & 1 & 12 & 6 & 10 & 22 & 24 & 12 & 2 & 1 & 0 & 9.00 \\
\hline \multirow[b]{2}{*}{11} & \multirow[b]{2}{*}{ Mysuru } & Hunsur & 89 & 20 & 0 & 3 & 11 & 3 & 6 & 39 & 28 & 10 & 1 & 6 & 2 & 10.75 \\
\hline & & Mysuru & 92 & 12 & 5 & 2 & 6 & 1 & 2 & 26 & 39 & 12 & 0 & 4 & 2 & 9.25 \\
\hline \multirow{2}{*}{12} & \multirow{2}{*}{ Raichur } & Raichur & 84 & 42 & 12 & 7 & 36 & 15 & 28 & 60 & 58 & 22 & 5 & 0 & 4 & 24.08 \\
\hline & & Lingsugur & 79 & 28 & 6 & 5 & 24 & 16 & 23 & 52 & 46 & 30 & 8 & 3 & 2 & 20.25 \\
\hline \multirow[b]{2}{*}{13} & \multirow[b]{2}{*}{ Tumakuru } & Tumakur & 92 & 8 & 2 & 0 & 10 & 8 & 8 & 29 & 28 & 8 & 2 & 0 & 2 & 8.75 \\
\hline & & Tiptur & 90 & 11 & 0 & 3 & 6 & 2 & 4 & 18 & 20 & 15 & 2 & 0 & 1 & 6.83 \\
\hline \multicolumn{4}{|c|}{ Mean } & 19.18 & 3.83 & 3.06 & 16.33 & 6.22 & 14.39 & 39.72 & 38.50 & 16.83 & 4.0 & 2.44 & 1.72 & \\
\hline
\end{tabular}


From Hassan taluk of Hassan district, the seed sample collected showed the maximum association of $P$. notatum (41\%) followed by F. oxysporum (28\%), Cladosporium sp. (25\%), M. phaseolina (20\%), A. niger (16\%), A. flavus (15\%), Mucor sp. (6\%), A. alternata (4 \%) and C. lunata (2\%). The observed results were matched with Zaidi and Pathak (2013) they observed Fusarium oxysporum. Alternaria alternata, Chaetomium spp, Penicillium citrinum, Aspergillus niger, A. flavus and Rhizopus nigricans relation with Mungbean seeds.

Kalaburgi district recorded maximum association of of $F$. oxysporum $(65 \%)$ followed by $P$. notatum (62\%), M. phaseolina (46\%), A. niger (36\%), A. flavus (30\%), Cladosporium sp. (26\%), A. candidus (14\%), A. aternata (10\%), C. lunata (8\%), Mucor sp. (8\%) and C. globosum (2\%). Similar species of Alternaria, Aspergillus, Chaetomium, Cladosporium, Curvularia, Drechslera, Fusarium, Mucor, Rhizopus and Trichoderma were reported by Ramesh and Avitha Marihal (2002) in association with the soybean crop seeds.

Seed sample collected from Srirangapattanataluk of Mandya district recorded maximum association of $P$. notatum (24\%) followed by $F$. oxysporum. (22\%), A. niger (18\%), M. phaseolina (12\%), A. flavus (12\%), Cladosporium sp. (10\%), A. candidus (6 \%), Mucor sp. (6\%), R. stolonifer (2\%), Mucor sp. (1\%) and C. lunata (1\%). Tanuja (2015), Dawar et al., (2007) and Ushamalini and ParameshaNaik (2008) found the similar findings during their studies on seed mycoflora.

Out of two seed samples collected from Mysuru district, sample from Hunsurtaluk recorded maximum association of seed mycoflora. Maximum association was by $F$. oxysporum (39\%) followed by $P$. notatum
(28\%), A. niger (20\%), A. flavus (11\%), M. phaseolina (10\%), Cladosporium sp. (6\%), Mucor sp. (6\%), A. candidus (3\%), C. lunata (3\%), C. globosum (2\%) and R. stolonifer (1\%). Seed sample collected from Mysurutaluk showed the maximum association of P. notatum (39\%) followed by $F$. oxysporum (26\%), A. niger (12\%), M. phaseolina (12 \%), A. flavus (6\%), A. alternata (5 \%), Mucor sp. (4 \%), Cladosporium sp. (2\%), C. globosum (2\%), C. lunata (2\%) and A. candidus (1 \%). Krishnamurthy et al., (2003) also reported many fungal species viz., $M$. phaseolina, $F$. semitectum, $F$. moniliforme, A. alternata, A. terrus, A. flavus and $F$. solani from mung bean seed samples collected from Chamarajanagar, Mysore and Gundlupettaluks of Karnataka.

Out of two seed samples collected from Raichur district, sample from Raichurtaluk recorded maximum association of seed mycoflora. Maximum association was by $F$. oxysporum (60\%) followed by $P$. notatum (58\%), A. niger (42\%), A. flavus (36\%), Cladosporium sp. (28 \%), M. phaseolina (22\%), A. candidus (15\%), A. alternata (12\%), C. lunata (7\%), R. stolonifer (5\%) and $C$. globosum (4 \%). Seed sample collected from Lingsugur taluk showed the maximum association of by $F$. oxysporum $(52$ $\%)$ followed by $P$. notatum (46 \%), $M$. phaseolina (30\%), A. niger (28\%), A. flavus (24\%), Cladosporium sp. (23\%), A. candidus (16\%), R. stolonifer (8\%), A. alternate (6 $\%)$, C. lunata (5\%), Mucor sp. (3\%) and C. globosum (2 \%). Ramesh et al., (2013) also reported identical seed mycoflora from thesamples collected from MARS and APMC units, Raichur.

Out of two seed samples collected from Tumakuru district, sample from Tumakurutaluk recorded maximum association of seed mycoflora. Maximum 
association was by $F$. oxysporum (29\%) followed by $P$. notatum (20\%), A. flavus (10 $\%)$, A. niger (8\%), Cladosporium sp. (8\%), M. phaseolina (8\%), A. candidus (8\%), A. alternate (2\%), R. stolonifer (2\%) and $C$. globosum (2\%). Seed sample collected from Tipturtaluk showed the maximum association of $P$. notatum $(20 \%)$ followed by $F$. oxysporum (18\%), M. phaseolina (15\%), A. niger (11\%), A. flavus (6 \%), Cladosporium sp. (4\%), C. lunata (3\%), A. candidus (2\%), $R$. stolonifer (2\%) and C. globosum (1\%). Raij Naik and Papanna (2001) reported Rhizopus sp, Aspergillus sp and Fusarium sp. in association with green gram.

The predominant fungi detected in the order of prevalence were found to be $F$. oxysporum (65\%), followed by Penicillium sp. (62\%), M. phaseolina (46\%), A. niger (42\%), A. flavus (36 \%), Cladosporium sp. (28\%), A. candidus (16 \%), Rhizopus sp. (12\%), Alternaria sp. (12\%), Mucor sp. (8\%), C. lunata (8\%) and C. globosum (4\%). Highest seed mycoflora was recorded in Kalaburgi $(25.73 \%)$ fallowed by Raichur $(24.08 \%)$ and Bagalkot districts (16.33\%) and lowest seed mycoflora was seen in Tumakuru, Mandya and Mysuru districts of Karnataka.

Current study revealed the prevalence of seed mycoflora differs from districts to districts, this may be due to weather conditions prevailing in different districts which might have favoured association of certain mycoflora associated with the seed samples. Tanuja (2015) also observed prevalence of seed mycoflora differ from location to location.

During the present investigation also, similar fungi were associated with mung bean seeds in different districts. Seeds are the efficient carriers for survival, large scale and long distance spread of pathogens. Infected or contaminated seeds serve as major source of inoculum for large number of plant pathogens which may infect the seeds and survive as spore or resting structures on or with in the seeds (Neergaard, 1977). This investigation opens the new avenues in studying and managing the seed mycoflora to get better management strategies.

\section{References}

Anonymous. 1996. International rules of seed testing. Seed Sci. Tech., 24: 1-335.

Anonymous, 2011. Area, Production and Productivity of Green gram in major states. Agropedia, Zonal Project Directorate, Kanpur, 18 pp.

Bilgrami, K.S., Prasad, T. and Sinha, R.K. 1979. Changes in nutritional component of stored seeds due to fungal association. Today and Tomorrows printers and publishers, New Delhi, 82 pp.

Booth, C. 1971. The genus Fusarium. Common Wealth Mycological Insitute, Kew, Surry, England, $237 \mathrm{pp}$.

Burnett, H.L. 1972. Illustrated genera of Imperfect Fungi, Burges Pub Com., Minnesota, and $213 \mathrm{pp}$.

Chakravarthy, C.N., Thippeswamy, B. and Krishnappa, M., 2001. Seed borne mycoflora of pigeonpea (Cajanus cajan L.) in Karnataka Nat. Sem. "Recent trends in plant disease management" Kuvempu University, Jnana Sahyadri, Karnataka, $67 \mathrm{pp}$.

Chatterjee, D. and Randhawa, G.S. 1952. Standardized names for cultivated plants in India-II. Cereals, Pulses, Vegetables and Spices. Indian J. Hort., 9: 64-84.

Christensen, C.M. and Lopez, L.C. 1963. Pathology of stored seeds. In: Proc. Inter. Seed. Test. Ass., 28: 701-712.

Dawar, S., Farzana Syed and Ghaffar, A. 2007. Seed borne fungi associated with chickpea in Pakistan. Pak. J. Bot., 39(2): 637-643.

Krishnamurthy, Niranjana, S.R. and Shetty, H.S. 2003. Effects of chemical fungicides and biological agent on seed quality improvement in pulses. Seed Res., 31(1): 121-124. 
Mukhtar, T., Hussain, M.A., Irfan Ulhaque, M. and Kayani, M.Z. 2007. Mycoflora associated with lentil (Lens esculenta Moench) seeds from five localities of Punjab, Pakistan. Pak. J. Bot., 39(3): 903906.

Narayan, M.G. and Ayodhya, D.K. 2013. Study of seed borne fungi of different legumes, Trends in life Sci., 2: 2319-4731.

Neergaard, P. 1977. Seed Path, Vol I and II. McMillan Press, London, UK, p.1187.

Raij Naik and Papanna, K. 2001. Seed borne mycoflora of green gram of Chitradurga district, Nat. Sem. "Recent trends in plant disease management" Kuvempu University, Jnana Sahyadri, Karnataka, 67pp.

Ramesh, B.V., Hiremath, S.V., Naik, M.K., Amaresh, Y.S., Lokesh, B.K. and Vasudevan, S.N. 2013. Study of seed mycoflora of soybean from north eastern Karnataka, Karnataka J. Agric. Sci., 26(1): 58-62.

Ramesh, L.H. and Avitha Marihal, K. 2002. Seed mycoflora of soybean and percentage of incidence. Nat. Sem. "Plant health for food security" University of Mysore, Manasagangathri, Mysore, $289 \mathrm{pp}$.

Rauf, B.A. 2000. Seed-borne disease problems of legume crops in Pakistan. Pak. J. Sci. Indus. Res., 4: 249-254.

Schwin, F. 1994. Seed treatment: progress and prospect. BLK monograph No. 57. BCPC Publication, Famham, U.K., pp 3 -14.

Shalini Verma and Dahroo, N.P. 2003. Seed mycoflora on pea in Himachal pradesh. Nat, Sem, "Integrated plant disease management for sustainable agriculture" (IPDMSA) Annamalai University, 126pp.

Singh, D.S., Shukla, A.K. and Vasuniya, S.S. 1995. Seed health testing of some advanced cultivars. Indian J. Mycol. Pl. Pathol., 25: 321-322.

Subramanian, C.V. 1983. Hypomycetes taxonomy and biology. Academic press, London. vol I and vol II. $930 \mathrm{pp}$.

Tanuja, N. 2015. Investigations on seed mycoflora of Chickpea (Cicer arietinum L.) M.sc (Agri) Thesis, Univ. Agric. Sci, Bengaluru, 24-72pp.

Tomar, D.S., Reetisingh and Pandya, R.K. 2001. Mycoflora associated with guar (Cyamopsis tetragonolabaTaub.) Seeds and evaluation of fungicides and cow urine against Alternaraiacymopsidis. J. Mycol PI. Pathol., 32: 270.

Tripti Agarwal, Abhiniti, M. and Trivedi, P.C. 2011. Fungi associated with chickpea, lentil and black gram seeds of Rajasthan. Int. J. Pharma and Bio Sci., 2: 478-483.

Ushamalini and Paramesha Naik, D. 2008. Prevalence of mycoflora and mycotoxins in some storage seeds. Ecol. Environ. Conservation Paper, 449-451pp.

Van Gastel, A.J.G.V., Pagnatta, M.A., and Porceddu, E. 1996. Studies on seed health testing techniques for pulses. Seeds Sci. Tech., ICARDA, Aleppo, Syria, pp 289 295.

Venugopal Rao, T., Rajeswari, Keshavulu, K. and Sandeep Varma. 2015. Studies on seed borne fungi of soybean. Int. J. Agric. Envtl. Sci., (SSRG-IJAES).

Von Arx, J.A. and Cramer, J. 1981. The genera of fungi sporulating in pure culture. Inder A. R Gantierverlagkommadigesellschalt F.I. 9490 vaduz, pp 21-48.

Zaidi, R.K., and Pathak, N. 2013. Evaluation of seed infection of fungi in chickpea, e-J. Sci. Technol., 8(2): 28-36.

\section{How to cite this article:}

Devamani B.D., M. Saifulla, Jayappa and Jabbar Sab. 2017. Prevalence of seed mycoflora of Mung bean (Vigna radiata L.) in Karnataka, India. Int.J.Curr.Microbiol.App.Sci. 6(6): 844852. doi: https://doi.org/10.20546/ijcmas.2017.606.099 